\title{
C-type natriuretic peptide prevents activation of perivascular mast cells and inflammation in the postischemic microvasculature
}

\author{
Wen Chen ${ }^{1 *}$, Katharina Völker ${ }^{1}$, Birgit Gaßner ${ }^{1}$, Franziska Werner ${ }^{1}$, Anja Rabenhorst ${ }^{2}$, Karin Hartmann², \\ Michaela Kuhn ${ }^{1}$
}

From 7th International Conference on cGMP Generators, Effectors and Therapeutic Implications

Trier, Germany. 19-21 June 2015

\section{Background}

Atrial- and C-type- natriuretic peptides (ANP, CNP) are both vasodilatatory hormones which are mainly secreted from cardiac atria and vascular endothelium, respectively. Both peptides activate cyclic GMP (cGMP) formation by binding to their specific receptors: the particulate guanylyl cyclases A (GC-A) and B (GC-B). Cyclic GMP via cGMP-dependent protein kinase I (cGKI) was shown to inhibit mast cell (MC) degranulation [1]. During postischemic reperfusion, the activation of MC is detrimental [2]. Due to pleiotropic effects, cytokines released from MC cause tissue damage and vascular leakage. It is unclear whether and how ANP and/or CNP regulate the activity of MC and, thereby, influence ischemia-reperfusion-induced disruption of the microvascular barrier.

\section{Methods and results}

Intravital microscopy was used to visualize the microcirculation within the cremaster muscle of anesthetized mice, and Fluorescein isothiocyanate (FITC)-Dextran was injected intravenously to quantify the microvascular leakage $[3,4]$. Cremaster blood flow was temporally blocked with an arterial clamp to provoke $30 \mathrm{~min}$ of tissue ische$\mathrm{mia}$. During the following $30 \mathrm{~min}$ of postischemic reperfusion, the vascular leakage was measured by the ratio of the fluorescent (FITC-Dextran) intensity (RFI) between the adjacent interstitial space and the intravascular lumen. Subsequently resident perivascular degranulated MCs were stained by superfusing Ruthenium Red solution and thereafter counted (number per field).

\footnotetext{
* Correspondence: wen.chen@uni-wuerzburg.de

'Institute of Physiology, University of Würzburg, Würzburg, Germany

Full list of author information is available at the end of the article
}

In wildtype mice, ischemia-reperfusion (compared to sham operated cremaster muscles) provoked marked MC degranulation and robust vascular leakage of FITCDextran (as indicated by higher RFI). Local CNP superfusion during reperfusion significantly reduced the amount of degranulated MCs and concomitantly vascular leakage. These effects were mimicked by the membrane-permeable cGKI activator 8-Br-cGMP. The protective effects of 8-Br-cGMP were endothelium-independent, since they were preserved in mice with conditional, endothelial deletion of cGKI. Quantitative real-time RT-PCR revealed local CNP-mRNA expression in the m. cremaster, which was not altered by acute ischemia. In contrast to CNP, ANP superfusion did not significantly alter the amount of degranulated MCs, but still effectively reduced FITC-Dextran leakage resulted from ischemia-reperfusion. Accordingly, in vitro, in cultured human MCs (HMC-1.1, originally developed by Dr. Butterfield and a gift from Dr. Drube) and primary cultured murine bone marrow $\mathrm{MC}$, CNP, but not ANP, induced a marked increase in intracellular cGMP levels and enhanced the phosphorylation of the cytoskeleton-associated vasoactive stimulated phosphoprotein (VASP) at Ser237.

\section{Conclusions}

Our study shows divergent effects of NPs in the postischemic microcirculation. CNP inhibited the ischemic activation of resident, perivascular MCs and consequently the associated microvascular leakage, possibly via MC specific cGMP/cGKI signaling. At difference, ANP had no effect on MCs but still attenuated the postischemic vascular barrier disruption via direct effects on endothelial cells. Our future studies aim to dissect the 
vascular cell-specific effects and signaling pathways of both NPs and possible clinical implications.

\section{Acknowledgement}

Supported by the DFG (SFB 688).

\section{Authors' details}

'Institute of Physiology, University of Würzburg, Würzburg, Germany.

2Department of Dermatology, University of Cologne, Cologne, Germany.

Published: 2 September 2015

\section{References}

1. Nanamori M, Chen J, Du X, Ye RD: Regulation of leukocyte degranulation by CGMP-dependent protein kinase and phosphoinositide 3-kinase: potential roles in phosphorylation of target membrane SNARE complex proteins in rat mast cells. J Immunol 2007, 178(1):416-427.

2. Bortolotto SK, Morrison WA, Han X, Messina A: Mast cells play a pivotal role in ischaemia reperfusion injury to skeletal muscles. Lab Invest 2004, 84(9):1103-1111.

3. Chen W, Gaßner B, Nikolaev VO, Strasser RH, Feil R, Hofmann F, et al: Atrial natriuretic peptide enhances microvascular albumin permeability by the caveolae-mediated transcellular pathway. Cardiovasc Res 2011, 93(1):141-151.

4. Chen W, Oberwinkler $H$, Werner $F$, Gassner $B$, Nakagawa $H$, Feil $R$, et al: Atrial Natriuretic Peptide-Mediated Inhibition of Microcirculatory Endothelial $\mathrm{Ca} 2+$ and Permeability Response to Histamine Involves cGMP-Dependent Protein Kinase I and TRPC6 Channels. Arterioscler Thromb Vasc Biol 2013, 33(9):2121-2129.

doi:10.1186/2050-6511-16-S1-A41

Cite this article as: Chen et al: C-type natriuretic peptide prevents activation of perivascular mast cells and inflammation in the postischemic microvasculature. BMC Pharmacology and Toxicology 2015 16(Suppl 1):A41.

\section{Submit your next manuscript to BioMed Central} and take full advantage of:

- Convenient online submission

- Thorough peer review

- No space constraints or color figure charges

- Immediate publication on acceptance

- Inclusion in PubMed, CAS, Scopus and Google Scholar

- Research which is freely available for redistribution

Submit your manuscript at www.biomedcentral.com/submit
Biomed Central 